\title{
VERBAL AGGRESSION IN THE POLITICAL DISCOURSE OF DONALD TRUMP AND JOE BIDEN
}

\author{
Damir Yenikeyev \\ Postgraduate Student, Zaporizhzhia National University, Ukraine \\ e-mail: damiryenikeyev@gmail.com,orcid.org/0000-0003-4008-4045
}

\section{Summary}

This article is devoted to the study of verbal aggression. This question has been little studied in modern linguistics so far. The study analyzed the statements of Donald Trump and Joe Biden in the framework of political discourse. Types of verbal aggression were identified using the methods of content analysis, discourse analysis and pragmalinguistic analysis. In addition, the characteristics of the linguistic personalities of Donald Trump and Joe Biden in terms of their use of tools to actualize verbal aggression are identified. Language, speech and communication means are distinguished as well. The results of the conducted investigation show that verbal aggression is often used by language personalities in combination with other communication tactics. In turn, verbal aggression is a means of implementing various communication strategies. Prospects for further research are the development of a classification of verbal aggression, as well as a comprehensive scheme for analyzing this phenomenon in speech.

Keywords: communicative tactics, discourse, speech invective, speech behavior, eco-linguistics.

DOI: https://doi.org/10.23856/4712

\section{Introduction}

Nowadays, we observe a tendency towards the increasingly frequent use of communicative aggression. This phenomenon is most often found in political communication. Its main task in this aspect is to fight opponents for power and attention of voters. This intention is carried out by creating a positive image of oneself and a negative image of the opponent. For this, various marker words are used with the necessary connotation. If they are used successfully, the addressee manipulates the sender's opinion. This strategy can be carried out with the necessary argumentation and without arguments. Verbal aggression can be carried out on both the verbal and written levels.

But this phenomenon has not been sufficiently studied from the point of view of linguistic personolology, which shows the novelty and relevance of our research. The analysis uses the methods of pragmalinguistic, discourse and content analysis.

\section{The phenomenon of verbal aggression}

Man as an individual exists in an aggressive physical environment. The same phenomenon is found in linguistics. Despite the fact that verbal aggression is most often found in political discourse, we consider it relevant to study this phenomenon precisely on the basis of political statements.

With the help of verbal aggression, politicians try to achieve various goals. For this, various communication strategies and tactics are used. We consider verbal aggression to be one of the tactics of political discourse, which actualizes various communication strategies. 
Through the phenomenon of verbal aggression, we observe the deterioration of the situation in the environmental friendliness of political discourse. This leads to an even greater spread of speech impact in politics.

In this study, we analyzed the linguistic, speech and communicative methods and forms of manifestations of verbal aggression. We also analyzed different types of this phenomenon in different contexts of political communication.

Considering verbal aggression as one of the main communicative tactics of political discourse, we can say that it is relevant to study its explicit and implicit forms, which can also be expressed using paraverbal means. This question is little researched in philological science.

As the researchers note: «speech aggression in the form of an invective, i.e. discrediting an opponent by means of a text addressed to him requires careful study within the framework of institutional discourses» (Golovina, 2019: 200), that is, within the framework of political discourse, the analysis of verbal expressions of aggression is relevant.

The language is constantly evolving and changing. This process is due to the fact that society and language influence each other: «the process of interaction of language with the environment is bi-directional: society affects the language, and language, as a central component of the human psychosphere, affects the society as a whole and the individual, the moral and spiritual level of society at a certain time» (Shamne, 2010: 4).

Destructive phenomena in modern culture influenced the level of aggressiveness and the activation of the genre of speech invective: «today, the level of aggressiveness in the speech behavior of people is extremely high. The genre of speech invective has become unusually active, using a variety of figurative means of negatively assessing the behavior and personality of the addressee - from expressive words and phrases that are within the limits of literary usage, to crudely colloquial and devalued vocabulary. All these features of modern oral and, in part, bookwritten speech are a consequence of negative processes occurring in extra-linguistic reality; they are closely related to general destructive phenomena in the field of culture and morality» (Krysin, 2000: 385 - 386). This determines the relevance of studies of verbal aggression.

A number of reasons have influenced the fact that the phenomenon of verbal aggression has not been sufficiently studied. This issue was initially considered only in the aspect of psycholinguistics. For a broader study of this issue, it is necessary to turn to other scientific areas related to linguistic science.

In the past few decades, interest in the study of the phenomenon of verbal aggression has increased. The reason for this interest was the penetration of this phenomenon into such spheres of modern society as politics, media, business relations, etc.

Today there is no single definition of verbal aggression. A number of scientists offer their own definitions of this phenomenon.

O. N. Zavyalova offers such a definition of verbal aggression: «a form of speech behavior aimed at insulting or intentionally causing harm to a person, a group of people, organizations or society as a whole. Speech aggression is motivated by the aggressive state of the speaker and often aims to cause or maintain the aggressive state of the addressee. Therefore, speech aggression is a violation of ethical and speech norms» (Zav'jalova: 460). To highlight linguistic aggression in speech, one should pay attention to the deviations of speakers from the norms of speech etiquette in a particular situation.

For V. N. Stepanov verbal aggression is "provocative speech ... depicts and conveys a certain psychological state of the speaker for his interlocutor and, as it were, "infects" him, and the purpose of this is to evoke the desired internal state in the interlocutor, to arouse in him a special kind of psychological activity - communicative, based on the desire to meet the 
communicative requirements presented by the interlocutor» (Stepanov, 2003: 161). That is, the addressee's verbal aggression evokes a response from the addressee.

After analyzing a number of existing definitions, Y. B. Mozhginsky formulated the following definition of verbal aggression: «actions and statements aimed at causing harm, mental and physical pain to another creature» (Mozhginskij, 2006: 10). It is understood that this is a negative impact on the other person in general and on the linguistic person, in particular.

Scientist K. F. Sedov, by verbal aggression understands «purposeful communicative action aimed at causing a negative emotional and psychological state in the subject of speech impact» (Sedov, 2005: 33). It is verbal aggression that can be one of the tactics of discrediting an opponent during political debates, for example.

Authors of «Stylistic encyclopedic dictionary» proposed such a definition of verbal aggression: «the use of linguistic means to express hostility, hostility; a manner of speech that offends someone's pride, dignity» (Stylistic Dictionary, 2011: 340). Important in this definition is the emphasis on the linguistic aspect of this phenomenon.

For a better understanding of the normativity of communicative behavior, three levels should be distinguished: «1) linguistic normativity, i.e. the correct use of linguistic means both at the level of vocabulary and at the level of syntax of a sentence in accordance with existing language conventions; 2) conceptual normativity, i.e. compliance of speech action with the norms of general culture, morality, etc., as well as certain social norms; 3) normativity of behavior in certain practical situations of social interaction, determined by the corresponding stereotypes» (Shnejder, 2002: 78 - 79). Violation of the norms of communicative behavior directly affects the language environment.

Consideration of the phenomenon of verbal aggression from the position of ecolinguistics associated with stylistics, culture of speech and rhetoric is relevant and poorly studied.

The relationship between a person and the language environment actively influenced ecolinguistics: «Based on the analysis of various concepts of the relationship between a person and the surrounding linguistic environment, it is possible to identify important problem areas that can be subjected to ecolinguistic monitoring. At the same time, the language within the framework of ecolinguistics should be considered as a resource, a source of implementation of communication, which, being actualized, forms a linguistic environment» (Shamne, 2010: 153). One of such areas for ecolinguistic monitoring should be the political language environment.

It is in political communication that verbal aggression is most often encountered, since its main goal is to fight opponents for power and the sympathies of voters.

In the process of achieving these political goals, politicians use a variety of techniques and arguments: «speech serving the purposes of conquering power, using special arguments, methods of defense and attack, is a type of discursive (speech) weapon, the speech system is agonal, since agon as the first principle of social and speech structures of power determines the structure of the socio- and logosphere, turning speech into agonal demonstration» (Mikhal'skaja, 1996: 74). This is what influences the predominance of agonality in the speech system of politicians.

One of the initial tasks of politicians is to create a favorable image of oneself and a negative attitude towards one's opponent: «our social reality is largely structured and determined by language: a name or a linguistic designation can to a greater extent determine and condition our understanding of what is meant, and our attitude to it» (Blakar, 1987: 97). For this, certain marker words with the desired connotation are used.

Verbal aggression has a certain specificity, which consists in a special relationship between the addressee and the addressee: « setting the addressee that his position should be unconditionally 
accepted by the addressee. That is why speech aggression as speech behavior is without argument by definition» (Voroncova, 2006: 36). From this point of view, it can be concluded that speech aggression as a communicative tactic is opposed to an argumentative strategy.

Verbal aggression also extends not only to the verbal, but to the written level: « even if aggressive remarks arise only at the level of writing the text, they attract and retain the reader's attention, activate the audience, forcing everyone to mentally identify with one of the « irreconcilable opponents». Thus, speech aggression can be considered as quite effective, although not always correct» (Basovskaja, 2004: 257-263). The manifestation of verbal aggression, even at the level of writing of the text, can be an effective way to attract the attention of the audience to your side.

Verbal aggression plays an important role in political discourse: «it should be noted that verbal aggression is an integral and natural component of political discourse and is primarily associated with the implementation of its agonal function» (Shejgal, 2000: 131). Taking into account that «political discourse is a form of institutional discourse, since it is socially oriented and sets communication within the framework of social status-role relations (Karjakin, 2009: 201), then we can say that the norm is an important feature of political discourse.

One of the components of political discourse is agonism: «in political linguistics, agonality is interpreted as one of the basic characteristics of political discourse associated with the intention of the struggle for power» (Shejgal, 2004: 326). This intention is one of the key ones in the pragmaticon of the linguistic personality of a politician. In linguistics, agonality is divided into tolerant and intolerant. The one that is conflicting, associated with the identification of aggression.

Taking into account the fact that «speech aggression is a deliberate speech act in the sense that the user of the invective uses it so that the addressee and the audience who witnessed the speech aggression perceive it as a deliberately committed act» (Golovina, 2019: 207). Another important aspect of the analysis of verbal aggression in political discourse is the communicative intentions of the participants.

So, verbal aggression is an expression of the speaker's negative attitude to the interlocutor using verbal and paraverbal means of communication, which in political discourse is one of the strategies for implementing certain intentions of politicians.

3. Donald Trump and Joe Biden's use of speech aggression

Scientists identify various types of aggressive verbal behavior in political discourse. Based on the statements of Donald Trump and Joe Biden, we analyzed the means of expressing these types of verbal aggression in speech.

Personality criticism is often used by politicians: I did say that to him, yes. And - and his response was, "We understand one another." It was - I wasn't being a wise guy. I was alone with him in his office. And that - that's how it came about. It was when President Bush had said, "I looked in his eyes and saw his soul. I said, "Looked in your eyes and I don't think you have a soul." And looked back and he said, "We understand each other." Look, most important thing dealing with foreign leaders in my experience, and I've dealt with an awful lot of 'em over my career, is just know the other guy. Don't expect somethin' that you're-that-don't expect him to - or her to - voluntarily appear in the second editions of Profiles in Courage. (Biden). In this interview, Joe Biden discredits his political opponent with the help of a generalized criticism of personal qualities.

Donald Trump combines verbal aggression with the tactics of giving examples and facts: I don't know. Somebody went through Wall Street. You're the one that takes all the money from Wall Street. I don't take it. Joe, you have raised a lot of money, tremendous amounts of money. And every time you raise money deals are made, Joe. I could raise so much more money (Trump, 2020). 
Ability criticism is often combined with comparison tactics in their favor: I did it, and I did it very well - I did, I think, perfectly — and a lot of people are suggesting that he do that. He would not pass it. He would not do well on it. But a lot of people are suggesting that he do that (Trump).

Criticism of the actions of opponents is one of the most effective types of verbal aggression, as it is most supported by arguments: It was a horrible decision going into the Middle East. And I know the Bush family will not be happy, but I believe it was the worst decision in the history of our country when we decided to go into the Middle East. It's turned out to be quicksand. We have destroyed the Middle East (Trump).

Expressions with implicit insults are also verbal aggression: We were respected all over the world. China was paying us billions and billions of dollars of tariffs. Companies were moving back into our country and China respected us. And frankly, they respected me. But you look, Russia, I had the pipeline stopped. Totally stopped. Biden comes in. He approves that pipeline, but he disapproves the Keystone XL Pipeline. You need a president that's respected (Trump).

In addition to his personal dislike, a politician may refer to other influential personalities who also do not sympathize with his opponent: They criticized me when I talked to Kim Jong-un. Well, President Biden told me it's the single biggest problem we have. I said, "Have you ever called him? Have you ever talked to him?" "No, I haven't." He did try but he was not receptive on the other side, but he was receptive with me. Now we were supposed to have a war and probably a very big nuclear war. I get along with him great and I got along with him great. He doesn't like Biden much, I'll tell you that. But I got along with him great and we had no problems. You remember that? (Trump).

Donald Trump, in addition to direct criticism and comparison with his actions, also shows the difference between his policies and those of Joe Biden: I rebuilt the military. We had an obsolete military. We had old jets, we had 45-year-old jets. We rebuilt this military and created Space Force. But the answer is I'd like to help, but you have to do it through the strength of the President's office and Biden has dissipated that strength. We are no longer respected (Trump).

Another type of verbal aggression is pointing out mistakes and unfulfilled promises of opponent Joe Biden: Firstly, we're going to make sure we're in a situation that we actually protect pre-existing. There's no way he can protect pre-existing conditions. None, zero. You can't do it in the ether. He's been talking about this for a long time. He's never come up with a plan. I guess we're going to get the pre-existing condition plan the same time we got the infrastructure plan that we waited for since '17, '18, '19, and 20. I still have a few more minutes. I know you're getting anxious (Trump, 2020).

Persistence in asserting negative traits or actions of the opponent is also a type of verbal aggression that Biden uses in arguments with his opponent: The expectation is we'll have another 200,000 Americans dead between now and the end of the year. If we just wore these masks, the president's own advisors have told him, we can save a 100,000 lives. And we're in a circumstance where the president thus far and still has no plan, no comprehensive plan. What I would do is make sure we have everyone encouraged to wear a mask all the time. I would make sure we move into the direction of rapid testing, investing in rapid testing. I would make sure that we set up national standards as to how to open up schools and open up businesses so they can be safe and give them the wherewithal, the financial resources to be able to do that (Biden, 2020).

The repetition technique is also used as a way to actualize verbal aggression: They tried to meet with him. He wouldn't do it. He didn't like Obama. He didn't like him. He wouldn't do it. I know for a fact. They tried. We wouldn't do it. And that's okay. You know 
what? North Korea, we 're not in a war. We have a good relationship. People don't understand. Having a good relationship with leaders of other countries is a good thing (Trump, 2020).

Criticism of biographical facts is used by politicians to implement a strategy of discrediting an opponent. Biden recalled the moment when Donald Trump hid the true state of affairs with COVID-19 from American citizens. According to Biden, Trump did not tell the whole truth because he did not want the Americans to panic and this was the wrong step on the part of the president: My response is that think about what the President knew in January and didn't tell the American people. He was told this was a serious virus that spread in the air, and it was much worse, much worse, than the flu. He went on record and said to one of your colleagues, recorded, that in fact he knew how dangerous it was but he didn't want to tell us. He didn't want to tell us because he didn't want us to panic. He didn't want us... Americans don't panic (Biden, 2020).

Verbal aggression in international political discourse is considered a gross violation of norms. When asked if Joe Biden considers the Russian president to be the murderer, he replied I do. Thus, he criticized some facts from the biography of Vladimir Putin: GEORGE STEPHANOPOULOS: So you know Vladimir Putin. You think he's a killer? RESIDENT JOE BIDEN: Uh-huh. I do (Biden).

Listening to Biden's campaign promises for the 2020 elections, Trump stressed that Biden has been in power for 47 years and has done nothing. He had a chance to improve the lives of Americans, but he did not take it. Inoculating these facts, Trump insisted on the insincerity and untruthfulness of Joe Biden's words: Excuse me. He was there for 47 years. He didn't do it. He was now there as vice president for eight years. And it's not like it was 25 years ago. It was three and three quarters... It was just a little while ago, right? Less than four years ago. He didn't do anything. He didn't do it. He wants socialized medicine. And it's not that he wants it. His vice president, she is more liberal than Bernie Sanders and wants it even more (Trump, 2020).

I wish to show my innocence in the situation with the withdrawal of troops from Afghanistan, Joe Biden said that she only continued to fulfill the agreements of the past president with the Taliban. Thus, he tried to shift all responsibility from himself to his predecessor: When I came into office, I inherited a deal that President Trump negotiated with the Taliban. Under his agreement, U.S. forces would be out of Afghanistan by May 1, 2021, just a little over three months after I took office. U.S. forces had already drawn down during the Trump administration from roughly 15,500 American forces to 2,500 troops in country. And the Taliban was at its strongest militarily since 2001. The choice I had to make as your president was either to follow through on that agreement or be prepared to go back to fighting the Taliban in the middle of the spring fighting season (Biden, 2021).

Parrying accusations of ill-treatment of people on the border between the United States and Mexico, Trump said that he did everything he could to protect the United States from illegal migrants. According to Donald Trump, all the places where people were kept at the border in poor conditions were built during the time when Biden was vice president: We now have as strong a border as we've ever had. We're over 400 miles of brand new wall. You see the numbers. And we let people in, but they have to come in legally and they come in through But let me just tell you. Let me just tell you. They built cages. They used to say I built the cages, and then they had a picture in a certain newspaper, and it was the picture of these horrible cages and they said, "Look at these cages. President Trump built them." And then it was determined they were built in 2014. That was him. They built cages (Trump, 2020). 
Appearance criticism as a type of verbal aggression is often used in humorous or ironic comments. In an era of tense relations with North Korea, the 45th President of the United States made many statements about the opposite country. After one of these statements in his Trump noticed that she, too, could criticize the leader of North Korea, but he does not: Why would Kim Jong - un insult me by calling me 'old', when I would never call him 'short and fat'? Oh, well I try so hard to be his friend - and maybe someday that will happen (Trump).

In wish to attract the attention of the audience and show the strength next to Trump in defending his opinion Biden uses an incorrect phrase in political circles shut up: Will you shut up, man? (Biden, 2020).

Another type of verbal aggression is ridicule, which is unacceptable in official discourse. In an interview, Donald Trump said that, in his opinion, Biden's political moves make China laugh, which is the main geopolitical adversary of the United States: I will say when China watches this, they're so happy and they're laughing at us. They're laughing. I extracted billions and billions of dollars out of China. It never happened. We never got 25 cents from China. Billions and billions. They was so happy to see a rigged election. They might've helped it along actually, but they were so happy. But Sean, I'Il tell you what, this is the greatest embarrassment that I've ever seen (Trump).

Wanting to ridicule Trump as President of the United States, Joe Biden gives an example of Trump's words about the coronavirus and how he was initially wrong: и намерено врал людям. And by the way, this is the same fellow who told you, "This is going to end by Easter" Iast time. This is the same fellow who told you that, "Don't worry, we're going to end this by the summer." We're about to go into a dark winter, a dark winter and he has no clear plan. And there's no prospect that there's going to be a vaccine available for the majority of the American people before the middle of next year (Biden, 2020).

Sometimes verbal aggression can be expressed in giving opponents mocking nicknames: Crooked Hillary Clinton is the worst (and biggest) loser of all time. She just can't stop, which is so good for the Republican Party. Hillary, get on with your life and give it another try in three years! (Trump)

In the context of the study of verbal aggression, one should also analyze the recipient's reaction to negative statements: When I closed and banned China from coming in heavily infected and then ultimately Europe, but China was in January. Months later, he was saying I was xenophobic. I did it too soon. Now he's saying, "Oh, I should have moved quicker," but he didn't move quicker. He was months behind me, many months behind me (Trump, 2020).

Expressive units are one of the main means of expressing verbal aggression: It's a great thing that we're getting out, but nobody has ever handled a withdrawal worse than Joe Biden. This is the greatest embarrassment, I believe, in the history of our country (Trump, 2021).

Another way is the ironic use of linguistic units with an initially positive connotation for implicit insult: Did you use the word smart? So you said you went to Delaware State, but you forgot the name of your college. You didn't go to Delaware State. You graduated either the lowest or almost the lowest in your class. Don't ever use the word smart with me. Don't ever use that word. Because you know what? There's nothing smart about you, Joe. 47 years you've done nothing (Trump, 2020).

Threats are a type of verbal aggression. Observing what happened in the situation with the withdrawal of troops from Afghanistan, Donald Trump threatened those who would harm the Americans: I spoke on numerous occasions to the head of the Taliban and we had a very strong conversation. I told him up front, I said: "Look, before we start, let me just tell you right now that if anything bad happens to Americans or anybody else, or if you ever 
come over to our land, we will hit you with a force that no country has ever been hit with before, a force so great that you won't even believe it. And your village, and we know where it is..." and I named it, "will be the first one. The first bombs will be dropped right there (Trump, 2021).

Hidden threat warning is also a form of verbal aggression: I shared with our allies what I'll convey to President Putin, that I'm not looking for conflict with Russia, but that we will respond if Russia continues its harmful activities. We will not fail to defend the transatlantic alliance or stand up for democratic values. As allies, we also affirmed our continued support for the sovereignty and territorial integrity of Ukraine (Biden).

The most explicit means of expressing linguistic aggression are swear words. In the spring of 2021, at a meeting of the Republican Party, Trump discussed with party members the situation with the 2020 presidential election. Analyzing the reasons for the loss, he stressed that some officials were inactive and did not intervene, defending the correctness of the Republicans. Trump named Schumer dumb son of a bitch. It was he who, according to Trump, should have acted, and not kept silent. "If that were Schumer instead of this dumb son of a bitch Mitch McConnell, they would never allow it to happen. They would have fought it" (Trump, 2021), he said of the election certification on Jan. 6, the day his supporters led an insurrection on the Capitol to block President Biden's formal victory.

While visiting Ukraine in 2015, Biden demanded the dismissal of the attorney general. He gave a certain time for execution. Got the desired result, he named the dismissed official son of a bitch I use unacceptable vocabulary in political circles: I'm leaving here in six hours. If the prosecutor's not fired, you're not getting the money... Well, son of a bitch, he got fired (Biden).

Non-verbal signs can also express aggression. Speaking about his relationship as president with the Taliban 45, the US president talked about how he canceled a meeting with them. This was due to unacceptable actions by the Taliban. Thus, with the help of non-verbal means, he showed his strength: I have to tell you that, if you remember, when they were coming to Washington to meet with me, they decided to kill an American soldier, because they thought that was a good way to negotiate. And I canceled the trip (Trump).

The statement of the possibility or impossibility of certain actions of the opponent in the future is also a type of verbal aggression: When I was in charge of the recovery act with $\$ 800$ billion, I was able to get $\$ 145$ billion to local communities that have to balance their budgets and states that have to balance their budgets. And then they have to fire firefighters, teachers, first responders, law enforcement officers, so they could keep their cities and counties running. He will not support that. They have not done a thing for them. And Mitch McConnell said, "Let them go bankrupt. Let them go bankrupt." Come on. What's the matter with these guys? (Biden).

Another type of explicit verbal aggression is the accusation of lying.: You know who I am. You know who he is, you know his character, you know my character, you know our reputations for honor and telling the truth. I am anxious to have this race. I'm anxious to see this take place (Biden, 2020).

The use of harsh expressions is aimed at attracting the attention of the audience, as this does not correspond to the usual norms of political discourse: There are 50 former national intelligence folks who said that what he's accusing me of is a Russian plant. They have said that this has all the ... five former heads of the CIA, both parties, say what he's saying is a bunch of garbage. Nobody believes it except him and his good friend, Rudy Giuliani (Biden, 2020).

Argument tactics are often used to back up verbal aggression with facts: We're in $a$ situation now where the New England Medical Journal, one of the serious, most serious journals in the whole world said for the first time ever that the way this president has responded to this 
crisis has been absolutely tragic. And so folks, I will take care of this. I will end this. I will make sure we have a plan (Biden, 2020).

Persuasive tactics are often combined with different types of verbal aggression: He had nothing, he did virtually nothing. And then he gets out of the hospital and he talks about, "Oh, don't worry. It's all going to be over soon." Come on. There's not another serious scientist in the world who thinks it's going to be over soon (Biden, 2020).

Comparisons between the opponent and citizen voters are actively used to actualize verbal aggression: We have no choice. We can't lock ourselves up in a basement like Joe does. He has the ability to lock himself up. I don't know. He's obviously made a lot of money someplace, but he has this thing about living in a basement. People can't do that (Trump, 2020).

Opposition tactics are one of the ways to express verbal aggression: He says that we're learning to live with it. People are learning to die with it. You folks home will have an empty chair at the kitchen table this morning. That man or wife going to bed tonight and reaching over to try to touch, there out of habit, where their wife or husband was, is gone. Learning to live with it. Come on. We're dying with it, because he's never said (Biden, 2020).

Responding to threats from other politicians is also seen as responding to verbal aggression: North Korean Leader Kim Jong Un just stated that the "Nuclear Button is on his desk at all times." Will someone from his depleted and food starved regime please inform him that I too have a Nuclear Button, but it is a much bigger \& more powerful one than his, and my Button works! (Trump)

Threats as a manifestation of verbal aggression can also be used to implement a strategy of positive self-presentation: He will pay a price. I, we had a long talk, he and I, when weI know him relatively well. And I - the conversation started off, I said, "I know you and you know me. If I establish this occurred, then be prepared" (Biden)

Ironic nicknames for opponents are typical for manifestations of Donald Trump's verbal aggression: Rocket Man is on a suicide mission for himself and for his regime (Trump).

A characteristic feature of Joe Bilen's linguistic personality is the use of swearing in relation to opponents: You're a damn liar, man (Biden).

Insults against US citizens have been repeated more than once: You're a lying dog-faced pony soldier (Biden), which indicates a certain trend in the vocabulary of Joe Biden.

Joe Biden is not tolerant of any speech aggression: I probably have a much higher IQ than you do, I suspect (Biden), there are very numerous cases of his use of profanity, including using profanity: You're full of shit (Biden).

\section{Conclusions}

So, we have analyzed various types of verbal aggression and linguistic, speech, communicative ways of their implementation. The study proves that verbal aggression is one of the main communicative strategies of political discourse.

There are different types of verbal aggression, such as criticism of appearance, personality traits, actions, direct insult, ridicule, irony, implicit insult.

Verbal aggression is often used by linguistic individuals in combination with other communicative tactics. In turn, verbal aggression is a means of actualizing various communication strategies.

A characteristic feature of the expression of verbal aggression in Donald Trump's speech is its humorous effect, which can be achieved with the help of ironic connotations or author's neologisms-nicknames. 
A characteristic feature of the expression of verbal aggression in Joe Biden's speech is the politician's use of a lexicon that does not correspond to the norms of not only political, but also institutional discourse in general. The use of profanity and direct insults has become a trend in the politician's speech. He uses these linguistic units not only in relation to his opponents, but also to voters.

Prospects for further research are the development of a classification of verbal aggression, as well as a comprehensive scheme for analyzing this phenomenon in speech.

\section{References}

1. Basovskaja E. N. (2004). Tvorcy cherno-beloj real'nosti : o verbal'noj agressii v sredstvah massovoj informacii [Creators of Black and White Reality : On Verbal Aggression in the Mass Media]. Kritika i semiotika. [in Russian]

2. Blakar R. M. (1987). Jazyk kak instrument social'noj vlasti. Jazyk i modelirovanie social'nogo vzaimodejstvija [Language as an instrument of social power. Language and social interaction modeling] Moskow : Progress. P. 88-120. [in Russian]

3. Golovina N. M. (2019). Parlamentskie «neparlamentskie vyrazhenija» : rechevaja agressija kak ritoricheskaja strategija $v$ parlamentskom diskurse[Parliamentary "non-parliamentary expressions": speech aggression as a rhetorical strategy in parliamentary discourse]. Tribuna molodyh uchenyh. Psycholinguistic issues 3 (41). P. 200 - 215. DOI 10.30982/ 2077-5911-2019-41-3-200-215 [in Russian]

4. Voroncova T. A. (2006). Rechevaja agressija : kommunikativno-diskursivnyj podhod [Speech aggression: communicative-discursive approach] : avtoref. dis. d-ra filol. nauk : 10.02.19. Chelyabinsk. 43 p. [in Russian]

5. Zav'jalova O. N. Rechevaja ili jazykovaja agressija v russkom jazyke [Speech or linguistic aggression in the Russian language]. URL : http://iamruss.ru/rechevaya-ili-yazykovaya-agressiya-v-russkom-yazykel

6. Karjakin A. V. (2009). Vyrazhenie rechevoj agressii v diskursivnoj praktike A. Merkel' [Expression of speech aggression in discursive practice of A. Merkel]. Vestnik Volgogradskogo gosudarstvennogo universiteta. Serija 2 : Jazykoznanie, (1). P. 201-205. [in Russian]

7. Krysin L. P. (2000). Tolkovyj slovar' inojazychnyh slov [Explanatory dictionary of foreign words]. Moscow. [in Russian]

8. Mihal'skaja, A. K. (1996). Russkij Sokrat : Lekcii po sravnitel'no-istoricheskoj ritorike [Russian Socrates: Lectures on Comparative Historical Rhetoric]. Moscow : Academia. 192 p. \{in Russian] 9. Mozhginskij Ju. B. (2006). Agressivnost' detej i podrostkov : raspoznavanie, lechenie, profilaktika [Aggressiveness of children and adolescents: recognition, treatment, prevention]. Moscow : Kogito-Centr. 181 p. [in Russian]

10. Sedov K. F. (2005). Rechevaja agressija v povsednevnoj kommunikacii [Speech aggression in everyday communication]. Rechevaja agressija v sovremennoj kul'ture: Sb. nauch. tr. Cheljab. gos. un-t. Cheljabinsk. P. 32 - 37. [in Russian]

11. Stepanov V. N. (2003). Provokacionnyj vopros s tochki zrenija pragmalingvistiki [A provocative question from a pragmalinguistic point of view]. Moskovskij lingvisticheskij zhurnal. Issue .6, №2. [in Russian]

12. Stilisticheskij jenciklopedicheskij slovar' russkogo jazyka [Stylistic Encyclopedic Dictionary of the Russian Language]. (2011). 2-e izd., stereotip. Moscow : Flinta : Nauka. 696 p. [in Russian] 
13. Shamne N. L. ( 2010). Teoreticheskie osnovy postroenija algoritma jekolingvisticheskogo monitoringa [Theoretical foundations for constructing an algorithm for ecolinguistic monitoring]. Vestnik Volgogradskogo gosudarstvennogo universiteta. Ser. 2, Jazykoznanie, № 2 (12). P. 153-161. [in Russian]

14. Shamne, N. L. (2010). Jekolingvisticheskij monitoring regiona [Eco-linguistic monitoring of the region]. Kommunikativnye aspekty sovremennoj lingvistiki i lingvodidaktiki : materialy Mezhdunar. nauchn. konf. Volgograd: Izd-vo VolGU. P. 3-10. [in Russian]

15. Shejgal E. I. (2000). Semiotika politicheskogo diskursa [Semiotics of Political Discourse]. Volgograd. [in Russian]

16. Shejgal E. I. (2004). Semiotika politicheskogo diskursa [Semiotics of Political Discourse] : monografija. Moscow : Gnozis. 326 p. [in Russian]

17. Shnejder V. B. (2002). Kommunikacija, normativnost', logika [Communication, normativity, logic]. Ekaterinburg : Izd-vo Ural. un-ta. 250 p. [in Russian]

18. ABC News' George Stephanopoulos interviews President Joe Biden. URL : https://abcnews.go.com/Politics/transcript-abc-news-george-stephanopoulos-interviews-president-joe/story? id $=76509669$

19. Trump trades 'short and fat' bard with $N$ Korea's Kim. URL : https://www.bbc.com/news/world-us-canada-41958553

20. Trump; Biden Would Not Pass A Cognitive Test, "A lot Of People Are Suggesting Thay He Do That”. URL : https://www.realclearpolitics.com/video/2021/06/29/trump_biden_would_ not_pass_a_cognitive test_a_lot_of people_are suggesting that he do that.html

21. Trump : Hilary is the 'worst and the biggest loser of all time'. URL : https://www.wafb.com/story/36877856/trump-hillary-is-the-worst-and-biggest-loser-of-all-time/ 22. Trump election. URL : https://www.washingtonpost.com/politics/trumpmcconnellelection/2021/04/11/297a82da987911eb962b78c1d8228819 story.htm

23. Biden Speaks On Afghanistan Crisis As Taliban Regains Control NBC News. URL : https://www.youtube.com/watch?v=ffMGzawyHFA

24. Joe Biden Brags about getting Ukrainian Prosecutor Fired. URL : https://www.youtube.com $/$ watch? $v=L 09 X 8 L T w H I c \& t=77 \mathrm{~s}$

25. Trump Hannity full interview Fox News Trump speech Sean Hannity show tonight Bidem Afghanistan. URL : https://www.youtube.com/watch?v=m-W_OByNKQA

26. Final 2020 Presidential Debate Between Donald Trump, Joe Biden NBC News. URL : https://www.youtube.com/watch? $v=U C A 1 A 5 G q C d Q$

27. Presiden Trump and former VP Biden face off in first presidential debate - 9/29/2020. URL : https://www.youtube.com/watch? $v=Y 4 H Q z e I 8 F \_U \& t=917 \mathrm{~s}$

28. Trump and Kim in quotes : From bitter rivalry to unlikely bromance. URL : https://www.aljazeera.com/news/2019/2/28/trump-and-kim-in-quotes-from-bitter-rivalry-tounlikely-bromance

29. Donald Trump vs. Hillary Clinton III: The most memorable lines. URL : https://edition.cnn.com/2016/10/19/politics/presidential-debate-hillary-clinton-donald-trump-quotes/index.html

30. Linge M. K. Joe Biden's 12 worst gaffes of all time. URL : https://nypost.com/article/worst-joe-biden-gaffes/ 